研究論文

\title{
人の位置情報を取得するサービスの現状に関する調査
}

\section{Survey on the current status of services that acquire location}

\author{
information of people
}

\author{
三浦瑞貴 ${ }^{*}$, 梶川裕矢 ${ }^{1}$ \\ Mizuki MIURA $^{1 *}$, Yuya KAJIKAWA ${ }^{1}$
}

1. 東京工業大学

Tokyo Institute of Technology

厂105-0023 東京都港区芝浦3-3-6

*連絡先著者 Corresponding Author

モバイルデバイスの普及と様々な通信形態の確立により，モバイルデバイスの位置情報を用いた サービスは, 今後更に成長する可能性を秘めている. 本研究は, モバイルロケーションサービス(以 下 MLS)を対象として, MLS 提供者の役割, 技術, 機能の側面から MLS の特徴を記述し, それらの 関係性を明らかにすることを目的として分析を実施した. その結果, MLS の機能拡張におけるサード パーティの役割を強調している先行研究の結果とは異なり, 現在の MLS において様々な機能を提 供しているのは，位置情報取得のコア技術開発とモバイルデバイス用ソフトウェア開発を有する Google, Amazon, Facebook, Apple といった垂直統合型のプラットフォーム企業であり, ショートレンジ の位置情報取得技術を活用し, MLS の機能を拡充させていることを見出した.

The dissemination of mobile devices and the establishment of various communication modes enlarge a growth potential of services utilizing location information of mobile devices. The aim of this study is to describe the role of mobile location service (MLS) provider, MLS technology, and its function, and also to clarify the relationship among those. While previous literature has emphasized the role of third party in expansion of MLS functions, our results how that integrative platformers including Google, Amazon, Facebook, Apple play key roles provide diverse MLS functions, who have core technologies in acquiring location information and developing software for mobile devices and utilize short range information.

キーワード:モバイルロケーションサービス，位置情報，モバイルデバイス，ビッグデータ

Mobile location services (MLS), Location information, Mobile device, Big data 


\section{1 背景}

現代は，企業や組織が顧客やパートナーか ら膨大な量のデータを収集し, サービスや事 業に活用するビッグデータの時代にある [1]. 特にスマートフォン等のモバイルデバイス は，高い普及率と地理的に広いカバー率を有 しており，ユーザーの位置と移動をリアルタ イムに収集可能なインターフェースとして 注目されている $[2-4]$.

本研究では，モバイルデバイスの位置情報 により強化されるサービスであるモバイル ロケーションサービス [5]（以下 MLS)に着目 する．位置情報を提供するモバイルデバイス は，i-mode などに対応した従来の携帯電話， iphone などのスマートフォンだけでなく, ウ ェアラブルスマートウォッチ, 位置ロガー, カーナビゲーショシステムなど，多岐に渡る．

本研究はその中でも，携帯電話・スマート フォンを対象として，デバイスの位置情報に より強化されるサービスである MLS を分析す る．ここでの強化とは，位置情報とその他の 情報を組み合わせることで技術・機能を向上 させてビジネス上の付加価值を生み出すこ とを指す。
MLS は，「位置情報」と「付帯情報」の組み 合わせによって構成される $[6]$ ，位置情報は モバイルユーザーの位置を識別・取得したリ アルタイムの情報であり，付帯情報はMLS を 付加価值のあるサービスにするために必要 な情報と定義される [6] 。

MLS が最初にサービスとして提供されたの は 1999 年の米国連邦通信委員会の要請によ る緊急事態・救出の機能であり，その際は， 付帯情報は付与されていなかった。 その後, 目的地情報，探索物情報，地域情報，個人情 報，通話情報が付帯情報として加わり，それ ぞれナビゲーション，人・物の追跡，情報提 供, 広告提供, 課金・請求機能へと発展した.

Long et al，[7]は，「場所の識別は，革新的 で説得力のあるサービスをユーザーへ提供 寸るために組み合わせる必要がある幾つか の要素（技術・コンテキスト・その他）のひ とつに過ぎない」と指摘している.

また，現在では，スマートフォンに加え， 複数の位置情報デバイスとモーションセン サーを用いて，個人の位置履歴情報を取得す ることで，包括的かつ詳細な人の移動・行動 情報が収集されている $[8-10]$.

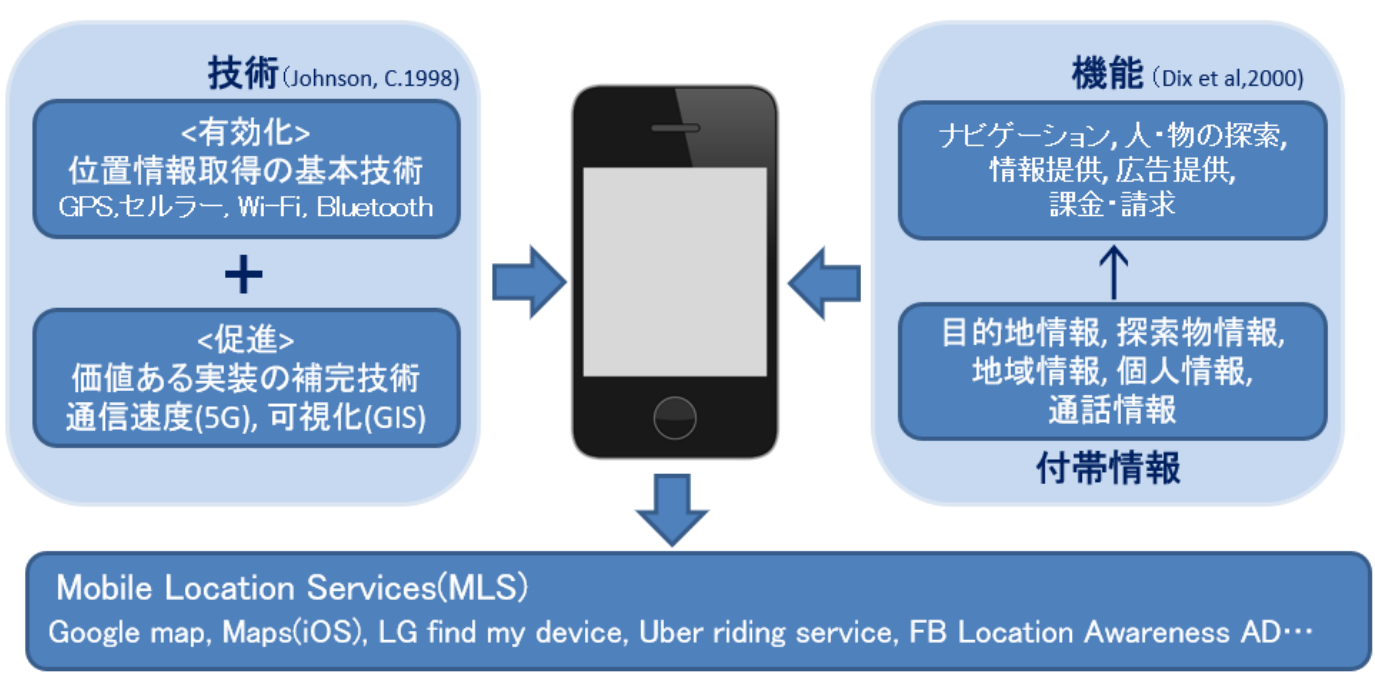

図 1 MLS の技術・機能マップ 
Johnson, C. [11]は, MLS テクノロジーを， 位置情報を取得する基本的な技術である「有 効化」技術と, MLS を付加価值のある方法で 実装するための補完的な位置づけである「促 進」技術に分類し，これらの組み合わせによ ってMLS のサービスを提供するシステムが構 築されることを示している。「有効化」技術 には，ロングレンジ（GPS/セルラーnet）とシ ヨートレンジ (Wi-Fi/Bluetooth) があり, カ バレッジ, 精度, アプリケーション環境が重 要となる.

MLS は位置情報の取得技術を含むMLS テク ノロジーと付帯情報・機能の組み合わせによ って実装されている（図 1). MLS は市場機会 に対して潜在的なアプリケーションが不足 していることが課題である [12] と指摘され ているが，これらの組み合わせ次第では，今 後新たなサービスが生まれる可能性もある.

Giaglis[13]は，このような新たなサービ スの創出は, MLS 提供者自身ではなく, サー ドパーティが担うものであり, MLS 提供者が 多様な役割を果たすことで発展するという 仮説を提示している。しかし，実サービスを 対象に, MLS の技術や機能, MLS 提供者やサー ドパーティの役割といった産業構造を分析 した研究は著者の知る限りまだ存在しない. そこで, 本研究では, 下記のリサーチクエス チョン $(\mathrm{RQ})$ を設定する.

$\mathrm{RQ1}$ : 現在の各 MLS は, どのような技術や機能 を有しているか? また, 技術と機能の関係性 はどのようなものか?

RQ2:MLS 提供者はどのような役割を果たして いるか? MLS 提供者の役割と提供する MLS の 技術や機能との間に関係はあるか?

以上を分析することで, MLS の技術と機能, MLS 提供者の役割を明らかにすることを本研 究の目的とする.

\section{2 データと分析手法}

\section{1 データ}

初めに, 分析対象とする MLS を抽出するた めに, ニュース記事データベースである DOW JONES FACTIVA データベースを用いて (https://www. dow jones. co. jp/products/pr oductfactiva/)" locationdata” or" locat ion information”を検索語として記事の抽 出を行った. 対象期間は 2019 年 1 月 1 日か ら 12 月 31 日までとした. 結果, 12,773 件が 該当した。

記事中より, DOW JONES FACTIVA データベ 一スが提供する会社の標準名を使用して，企 業名を抽出し, 結果, 115 社が抽出された。

本研究で DOW JONES FACTIVA データベース から取得した記事は，地域を日本に限定せず， 国内外の新聞記事オンライン版 (The Times, China Daily など)・トップニュースサイト （DOW JONES NEWS WIRES，共同通信など）か ら抽出している. 取得した情報には, 位置情 報に関する特許・法制度・商品化・企業間提 携や M\&A 情報が含まれる.

DOW JONES FACTIVA データベースから取得 した情報はニュースリリースされたもので あり，学術論文の情報は含まれない. その為, MLS に関する実装前の技術開発や大学との共 同研究などは分析に含まれないことを，情報 源に関する分析の限界として示す.

MLSの産業構造の概観を知るために, 同一 記事中での企業名の共起データをもとに， 企業間の関係性をVOS Viewerを用いて可視 化した(図2).

図2は，データベースから取得した位置情 報に関する企業115社が含まれる，本研究で は，多様性と関連性を考慮したスクリーニ ングを行った。具体的には, 位置情報の技 
術や機能の多様性をカバーするために, 図2 のクラスタの中心企業を選定するととも に, 自動運転技術の開発を行う企業など, MLS自体の提供を行わない企業を排除した。 結果, 115社の中から，30社を分析対象とし て選定した.

\section{2 分析手法}

対象とする 30 社の記事データに絞り, サ ービスの開始年を記録した. 各サービスの開 始年をもとに, 時系列に並べることで, MLS の 変遷が明らかとなる。

ただし，既存サービスのアップグレードの 場合，ニュース記事内にサービスの開始時期 が記されていない場合があり，その場合に限 り, 公式ウェブサイトをはじめ複数の情報ソ ースからサービスの開始時期を確認するこ ととした.

DOW JONES FACTIVA データベースから抽出 した記事のうち, 分析対象企業 30 社のサー ビスの開始時期が記されていない記事は 124 件存在した.これら 124 件については公式ウ ェブサイト, Wikipedia, Google Patent を参 照してサービスの開始時期を特定した。

また, 買収もしくは統合した後, ブランド 名を代えて再リリースされたサービスの場 合，買収した企業を軸として，リリースされ た年をサービスの開始時期とした.

これらの手順に従って抽出した調查対象 企業 30 社のデータを基に, 技術, 機能, MLS 提供者の役割の分析を行った. 技術面の分析 においては, 有効化技術, 促進技術のそれぞ れにおいて用いられている技術を抽出した。

有効化技術としてはロングレンジの Global Positioning System (GPS), ならび
にセルラーネットワーク，ショートレンジの Wi-Fi，Bluetooth 技術がある. 促進技術とし ては，通信速度と可視化 (GIS) が該当する.

機能については, 30 社の MLS に対する調査 の中で提供しているサービスの内容からキ ーワードを抽出し, リストを作成した.

MLS 提供者の役割については, Giaglis [13] のフレームワークを用いて分析を行った(図 3). 図 3 に, MLS 提供者の役割の類型を示す.

A. ポジショニングテクノロジー開発者は, モバイルロケーションサービスの基盤とな るテクノロジーの設計および実装する役割 を果たす事業者である.

A は更に a. ポジショニングテクノロジー プロバイダーと b. ポジショニングインフラ ストラクチャプロバイダに分岐する．前者は， 専用のモバイルハンドセットの位置を特定 するコアテクノロジーを提供し, 後者はモバ イル端末デバイスに組み込む必要のあるク ライアントソフトウェアを提供するため, 両 者の違いを明確にしている.

B. モバイルネットワークオペレーターは, セルラーネットワークを取り扱う通信会社 を指している.

D. サードパーティサービスプロバイダに は, GIS サービスプロバイダ, 広告代理店, ワイヤレスアプリケーションサービスプロ バイダが含まれる.

最後に, E. MLS の顧客(企業・個人) も MLS 提供者に含めている，Eは広告の宣伝など D の業務の一部を代行する役割として位置付 けている. 以上の手順を踏み, 技術, 機能, MLS 提供者の役割を明らかにするとともに, それらの間の関連性を分析した。 


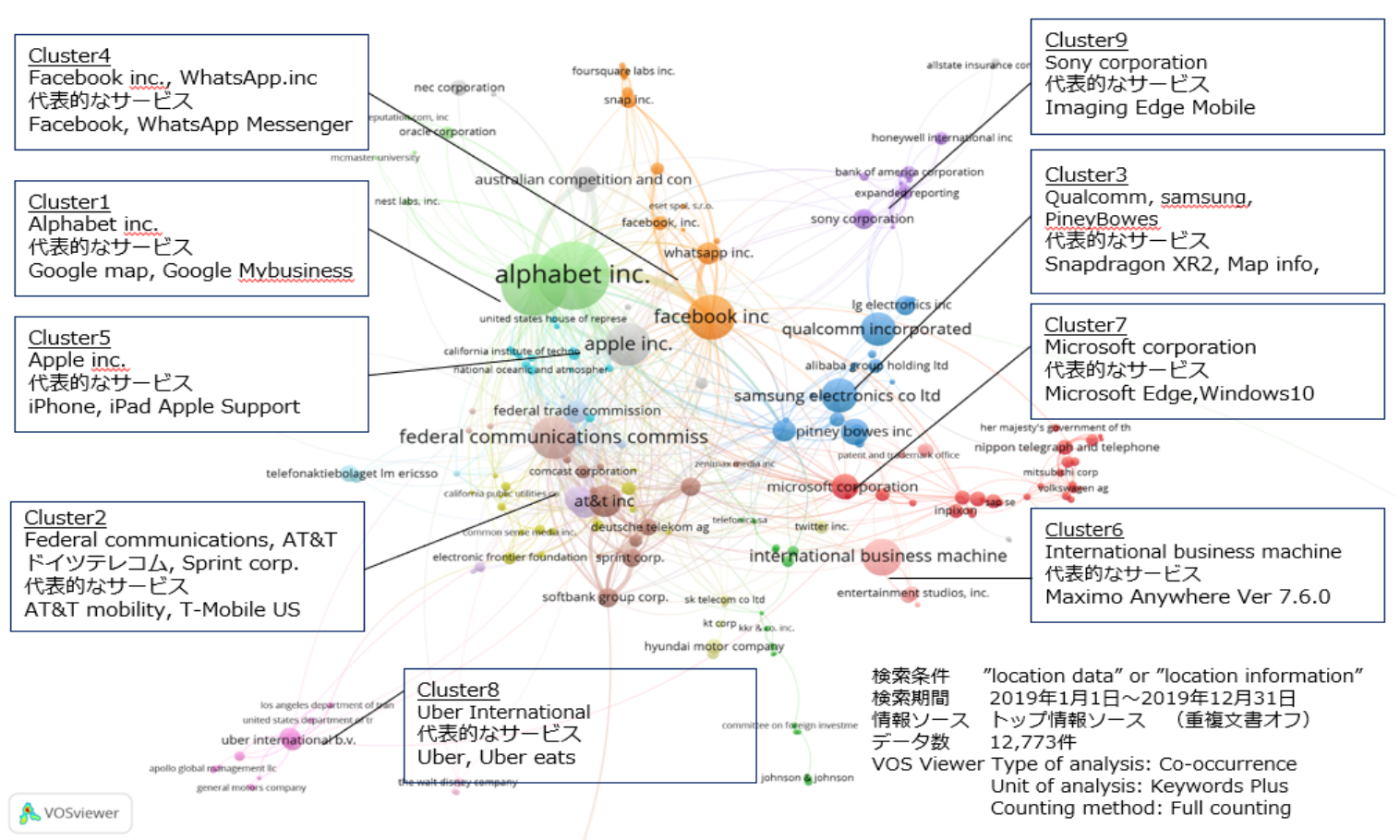

図 2 MLS の企業連関図 VOS Viewer (https://www. vosviewer.com/) を用いて作成

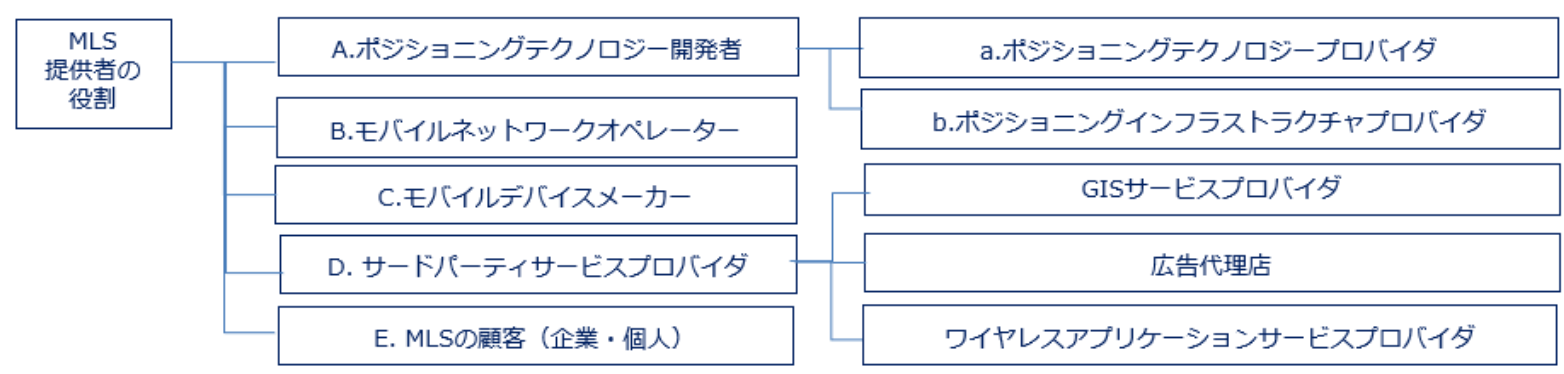

図 3 MLS 提供者の役割類型 Giaglis(2003) [13]をもとに作成

\section{3 結果}

\section{3. $1 \mathrm{MLS}$ 技術と機能の変遷}

表 1 は 30 社の MLS を構成する有効化・促 進技術を示している. 表 1 から読み取れるよ うに，有効化_ロングレンジと促進_通信速度 は全ての企業の MLS が採用しているのに対し て, 有効化_ショートレンジは 30 社中 14 社, 促進_可視化は 30 社中 18 社となっている.

有効化_ロングレンジと促進_通信速度は， 国によって多少の開始時期は異なるが，ほぼ 同時期である．以下，企業によって対応で差
があった有効化_ショートレンジ，促進_可視 化について詳細を記述する，有効化_ショー トレンジのWi-fi については, 2011 年以降, プラットフォーマー (Google, Apple, FB) と 通信会社(AT\&T, T mobile US, NTT) が，自 社商品の市場投入を行っている.

その後も, 2014 年に Google はスマートホ ームメーカーNest 社を買収, 2015 年に Google Nest Wi-fi を発表しており，2019 年には Amazon もメッシュ Wi-Fi ルーターメーカー EERO 社を買収し, ショートレンジの位置情報 を取得するための競争が激化している. 
促進_可視化でも同様に, 2012 年に Amazon が 3D地図アプリケーション企業 Up Next 社 を買収, 2014 年に Alibaba が地図アプリ開発 会社である高徳地図を買収, maps (iOS) で先 行する Apple も, 2015 年に Map Sense 社を買 収するなどM\&Aにより新規技術の獲得がなさ れている。

Johnson, C. [11]も, MLS は有効化だけで は成立せず，促進部分の技術開発と組み合わ せが重要であることを指摘しており, 今回の 調查結果に見られる傾向と合致する.

以上の結果から,Wi-Fi・Bluetooth による 近距離・屋内の位置情報取得と, GIS による 自社マップの強化は, 現在の MLS 技術の 2 大 トレンドとなっていることが分かる.

表 2 は, MLS 機能についての分析結果であ る. 機能を, ナビゲーション, 携帯電話探索, 荷物 - 車探索, 友達探索, 情報提供, 広告提 供, 請求・課金の 7 項目に分け, 企業名を示 している.ナビゲーションにおいては 30 社 中 22 社, 携帯電話探索は 9 社, 荷物・車探索 は 4 社, 友達探索は 7 社, 情報提供は 22 社, 広告提供は 11 社, 請求・課金は 6 社が対応 していることが読み取れる。

MLS の機能の変遷を見ると, 初期の情報提 供の後, 携帯電話探索が 2006 年以降の早く から，モバイルデバイスメーカー (C)によっ て実装されている，荷物・車の探索は，2011 年以降に Amazon や FedEx といった輸送を伴 う企業によって実装されている. Alibaba や Uber でも同様の MLS を自社開発している.

2014 年以降, 探索機能は, 友人と行きたい 場所を共有することができる Foursquare の アプリSwarmや，位置情報を開示した友人の 現在地を特定できる Facebook live location など, SNS と連動したコミュニケーションや マッチング機能へと拡張されている. MLS は,
携帯探索のような緊急時だけでなく, 荷物・ 車探索のような利便性向上, 友達検索といっ たコミュニケーション要素の追加と, サービ スが多様化してきていることが分かる.

\section{2 MLS提供者と技術 - 機能との関係性}

次に, MLS 提供者の役割と技術と機能との 関係性を分析した。表 3 ・表 4 から読み取れ るように, GAFA と呼ばれる企業群 (Google, Amazon, Facebook, Apple)の 4 社は, ポジシ ヨニングテクノロジープロバイダー (a)， ポ ジショニングインフラストラクチャプロバ イダ (b)の役割を兼社備えるとともに, 技術 面でも 4 社とも有効化技術(ロング・ショー 卜), 促進技術(通信速度・可視化) を備え, 多 様な機能を提供している.

b 群の企業も $\mathrm{a}+\mathrm{b}$ 群と同様, 幅広い技術と 機能をカバーしているが, 携帯探索機能は提 供できていない. $a+B$ の企業群 (AT\&T やNTT と いった通信会社) は，技術面では $a+b$ の企業 群と同様に広くカバーしているが, 機能面で は対比的に, ナビゲーション, 情報提供, 請 求に特化している.

C 群の企業も, $\mathrm{a}+\mathrm{B}$ の企業群と同様に, 特定 の機能 (ナビと携帯探索) に特化している. $\mathrm{b}+\mathrm{C}$ の企業群 (Sony, Tencent) は, 元々はデ バイスの製造を主力としていた企業であっ たが, 近年 MLS のアプリケーション開発や他 デバイスとの連動によるサービス化を行う ようになった企業である.

例えば, SONY はモバイルデバイスの製造を 行ってきたが，モバイルデバイスメーカー （C）とは異なる戦略を採っている。モバイル デバイスを単体で捉えず, カメラなどと連動 させてエッジデバイスとして機能するプラ ットフォームを構築することを掲げている.

MLS 提供者と技術との関係で特徴的なのは, 
有効化_ショートレンジ技術であり，プラッ トフォーマーと通信会社が 2015 年までに先 行して市場の開拓を行った後, 現在は Amazon やAlibaba などの $\mathrm{e}^{-}$コマース事業者がそれ を追う形となっており, 参入と非参入が二極 化している.

荷物・車の探索および友達の探索では，建 物内（倉庫・駅・店舗など）やトンネル通過 などにより GPS やセルラーネットワークが正 常に作動しないエリアでの正確な位置情報 の把握を行う上で, ショートレンジの位置情 報取得技術が活用されていた。

対して, 有効化_ロングレンジと促進_通信 速度では全てのMLS 提供者が対応している結
果となった.また, 促進_可視化においては, 全ての MLS 提供者で参入が確認された。 GIS はもはやサードパーティとして専業企業が 担う技術ではなく，前項で述べたように M\&A 等により広く各企業で内製化されている.

ただし，全ての企業がGIS を取り込んでい るわけではなく, サードパーティサービスプ ロバイダ(D)として GIS ベースの MLS を提供 するHere は，2015 年にドイツの自動車メー カー連合に売却されるまではNokiaの傘下に あり, 2011 年-2012 年は Nokia Maps として サービスを提供していた。しかし，おおまか な傾向としては，GIS は表 4 のように企業類 型によらず広く所有されているといえる.

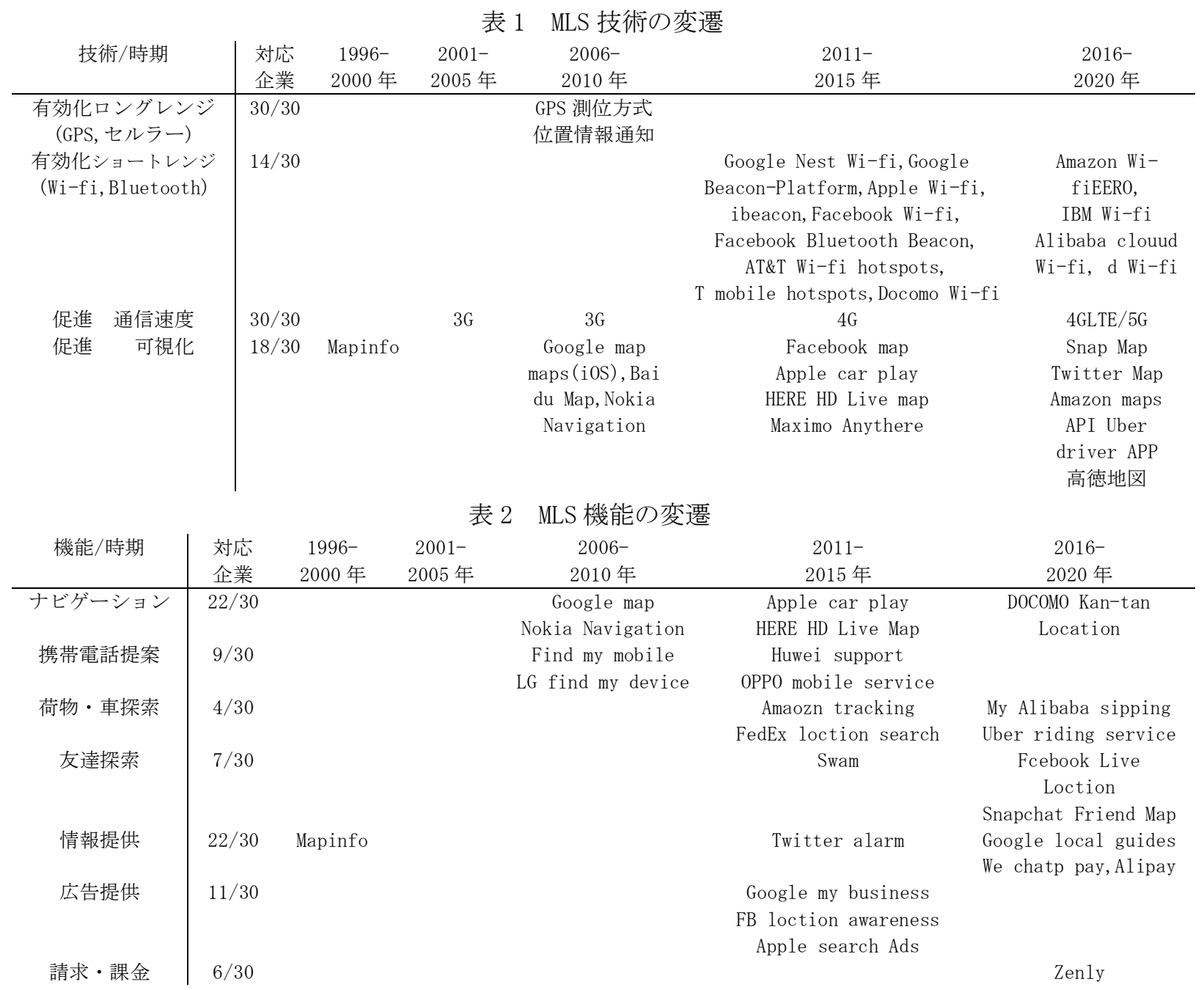




\begin{tabular}{|c|c|c|c|c|c|}
\hline $\begin{array}{l}\text { ポジション } \\
\text { /技術 }\end{array}$ & 該当企業 & $\begin{array}{c}\text { 有効化 } \\
\text { LR }\end{array}$ & $\begin{array}{l}\text { 有効化 } \\
\text { SR }\end{array}$ & $\begin{array}{c}\text { 促進 } \\
\text { 通信速度 }\end{array}$ & $\begin{array}{l}\text { 促進 } \\
\text { 可視化 }\end{array}$ \\
\hline$A+B$ & Alphabet/Google, Facebook, Apple, Amazon & $4 / 4$ & $4 / 4$ & $4 / 4$ & $4 / 4$ \\
\hline B & $\begin{array}{l}\text { IBM, WhatsApp, Twitter, Uber, Snap, } \\
\text { Alibaba, Baidu, Foresquare, FedEx }\end{array}$ & $9 / 9$ & $4 / 9$ & $9 / 9$ & $6 / 9$ \\
\hline$B+C$ & Sony, Tencent Technology & $2 / 2$ & $0 / 2$ & $2 / 2$ & $1 / 2$ \\
\hline$A+B$ & $\begin{array}{l}\text { At\&T, NTT, Sprint, SK telecom, T-mobile US, } \\
\text { Verizon }\end{array}$ & $6 / 6$ & $6 / 6$ & $6 / 6$ & $3 / 6$ \\
\hline C & $\begin{array}{l}\text { Samsung, Huawei, LG, Ericsson, Nokia, OPP0, } \\
\text { Motorola }\end{array}$ & $7 / 7$ & $0 / 7$ & $7 / 7$ & $2 / 7$ \\
\hline $\mathrm{D}$ & Pitney Bowes, HERE & $2 / 2$ & $0 / 2$ & $2 / 2$ & $2 / 2$ \\
\hline
\end{tabular}

表 4 MLS 提供者の役割と機能との関係

\begin{tabular}{|c|c|c|c|c|c|c|c|c|}
\hline $\begin{array}{c}\text { ポジション } \\
\text { /技術 }\end{array}$ & 該当企業 & ナビ & $\begin{array}{l}\text { 携帯 } \\
\text { 探索 }\end{array}$ & $\begin{array}{l}\text { 荷物 } \\
\text { 探索 }\end{array}$ & $\begin{array}{l}\text { 友達 } \\
\text { 探索 }\end{array}$ & $\begin{array}{l}\text { 情報 } \\
\text { 提供 }\end{array}$ & $\begin{array}{l}\text { 広告 } \\
\text { 提供 }\end{array}$ & 請求 \\
\hline$A+B$ & $\begin{array}{l}\text { Alphabet/Google, Facebook, Apple, } \\
\text { Amazon }\end{array}$ & $4 / 4$ & $2 / 4$ & $1 / 4$ & $3 / 4$ & $4 / 4$ & $4 / 4$ & $0 / 4$ \\
\hline B & $\begin{array}{l}\text { IBM, WhatsApp, Twitter, Uber, Snap, } \\
\text { Alibaba, Baidu, Foresquare, FedEx }\end{array}$ & $3 / 9$ & $0 / 9$ & $3 / 9$ & $4 / 6$ & $8 / 9$ & $6 / 9$ & $0 / 9$ \\
\hline$B+C$ & Sony, Tencent Technology & $0 / 2$ & $0 / 2$ & $0 / 2$ & $0 / 2$ & $2 / 2$ & $1 / 2$ & $0 / 2$ \\
\hline$A+B$ & $\begin{array}{l}\text { At\&T, NTT, Sprint, SK telecom, T-mobile } \\
\text { US, Verizon }\end{array}$ & $6 / 6$ & $0 / 6$ & $0 / 6$ & $0 / 6$ & $6 / 6$ & $0 / 6$ & $6 / 6$ \\
\hline $\mathrm{C}$ & $\begin{array}{l}\text { Samsung, Huawei, LG, Ericsson, Nokia, } \\
\text { OPP0, Motorola }\end{array}$ & $7 / 7$ & $7 / 7$ & $0 / 7$ & $0 / 7$ & $0 / 7$ & $0 / 7$ & $0 / 7$ \\
\hline D & Pitney Bowes, HERE & $2 / 2$ & $0 / 2$ & $0 / 2$ & $0 / 2$ & $2 / 2$ & $0 / 2$ & $0 / 2$ \\
\hline
\end{tabular}

\section{4 考察}

1996 年以降，MLS を牽引してきたのはB の ネットワークオペレーターやCのデバイスメ ーカーであり, Giaglis[13]の先行研究では 多様な役割を分担しながら追加サービスを 提供していくという予測結果を立てていた. また, Giaglis[13]は, サードパーティは「経 済的に内部化できない」としており，今後の MLS は MLS 提供者が多様な役割を分担するこ とによって発展すると主張していた.

しかし, 結果を見る限り, 機能を拡充させ て新しいサービスを精力的にリリースして いるのは, $\mathrm{a}$ と $\mathrm{b}$ を兼㸚る企業や $\mathrm{b}$ の企業と いうことがわかる. 内部化を可能にした企業 はいずれもポジショニングテクノロジープ ロバイダー (a)の役割を担っていることから， 位置情報のコアテクノロジーを有する企業 が，技術開発の川上とサードパーティサービ スの川下を抑えることで，MLS における垂直
統合を図ろうとしているということが推論 できる.

モバイルデバイスメーカー (C) は GPS・GIS を活用して, 2000 年代前半までMLSを牽引し たが，現在の MLS においては機能の拡充に至 っておらず，デバイスに関するサービスに特 化している．機能を拡充する技術を十分活か せていないのであれば，近距離の位置情報取 得に近年注力するネットワークオペレータ 一(B) と連携を取り, 両者の垂直統合や, サ一 ドパーティの拡充を図れば良いのだが，そう 簡単ではない.

何故なら, MLS がスマートフォンのアプリ ケーションを経由したサービスを開発する 場合, software development kit（SDK)のラ イセンスや規格はAndroid と iOS が指定して おり，B やC の企業が自由度の高いアプリケ ーションを構築することが極めて困難なた めである.

図 2 のフレームワークでは, MLS 提供者の 各役割を便宜的に並列としたが，実際に MLS 
のサービスを提供する場合, B と C の企業は D のサードパーティの立場でないと，アプリ ケーションの提供はできない。これは, 現代 のMLS がデバイスに依らずソフトウェアに起 因寸ることから，a と b を兼衫る企業以外で MLS 提供者の連携が進まないひとつの要因と なっている可能性がある.

これらのことから, 今後も MLS は $\mathrm{a}+\mathrm{b} の$ 企 業群が先導していく可能性が高いのではな いかと考察する.ただし, 既存の通信網に限 定することなくサービス展開していくこと も考えられる，例えば, SONY はエッジデバイ スとして機能するプラットフォームを構築 することを掲げており, 本調査からはショー トレンジは不使用だが，モバイルデバイスメ 一カー (C) とポジショニングインフラストラ クチャプロバイダ $(\mathrm{b})$ との比重を, 後者へよ りシフトすることが考えられる. そうなった 時には, 近距離の位置情報取得に注力するこ とも十分に想定され, エッジデバイスを起点 とした新たなMLSの展開も視野に入るものと 思われる。

分析の結果から, MLS において様々な機能 を提供しているのは, 位置情報取得のコア技 術開発 (a) とモバイルデバイス用ソフトウェ ア開発 (b) を有する GAFA (Google, Amazon, Facebook, Apple) と呼ばれるプラットフォ ーマー4 社であった.このことは、既存研究 における分析や考察とは異なる.

例えば、Kawai[14]は，5G 時代において， 既存の非プラットフォームビジネスは, GAFA を含む巨大なプラットフォーマーに劦かさ れているとしている.この GAFA のプラット フォームの特徵は,「群衆経済」であり, コン テンツプロデューサーとユーザーの間の仲 介役として機能していることである $[15]$.

Giag1is[13]は, MLS における新たなサービ
スの創出は，プラットフォーマーとしての MLS 提供者自身ではなく, サードパーティが 担うものであるとの仮説を提示している.

しかし，本研究が見出した GAFA 企業はプ ラットフォーマーとしての水平展開ではな く，多様な技術を取り込んだ垂直統合に向か っているという発見的事実を, 以下の 2 点の 要因から示す.

1 点目は, 現在、MLS の「モバイルデバイ ス」が携帯電話のみを想定したサービスでは なくなっていることである. Giaglis[13]の 先行研究は 2003 年であり, モバイルデバイ スは携帯電話を中心に据えられている。 Giaglis[13]の先行研究では描かれていない MLS の大きな潮流は, エッジコンピューティ ングによる IoT デバイスとの連動である.

位置情報は，モノのインターネット（IoT） の重要な部分の 1 つであり, IoT 領域のほと んどのサービスを改善するために重要な役 割を果たすことが期待されている $[16]$. この ことにより, 従来のネットワークオペレータ ーとモバイルデバイスメーカーを中心とす る水平分業体制からの移行が生じやすくな っていると考えられる。

2 点目は垂直統合による機会領域の拡大で ある. GAFA と呼ばれるプラットフォーマーは, 2015 年以降はモバイルデバイスを携帯電話 だけに留めず, ウェアラブルウォッチやスマ ートグラス，ホームデバイスといった個人の 生活領域の IoT と位置情報の連動に注力し, MLS 提供者の役割の垂直統合だけでなく, IoT 連動によるモバイルデバイスの水平展開も 同時に進めてきた.

その結果, 先行研究で示された 7 つ機能 によるサービス提供が，全方位的に可能とな っている.これによりサイバー空間とリアル 空間を統合した新たなサービスが生まれつ 
つある.例えば, Amazon は従来の配送におけ る位置情報の活用だけでなく, Amazon Go と いった実店舗でも位置情報を活用すること で，新たな付加価值を生み出している.

このように，リアル空間での位置情報を用 いたサービスと, サイバー空間での顧客情報 等を組み合わせたサービスの展開は, 本研究 で明らかにした垂直統合化の潮流により，今 後より加速することが予想される.

\section{5 結論}

本調查はMLS 提供者の役割と技術・機能と の関係性を明らかにすることを目的として， Factiva データベースの記事をもとに分析し た。その結果, MLS は 1996 年以降, ネットワ ークオペレーターとモバイルデバイスメー カーが中心となりサービスを提供, GPS・GIS を活用して発展したが，2011 年以降はWi-Fi およびBluetoothを用いて近距離の位置情報 取得を組み合わせたシステム構成が主流と なり, 様々な企業が参入しているということ を確認した。

また，MLS において様々な機能を提供して いるのは，位置情報取得のコア技術開発 (a) とモバイルデバイス用ソフトウェア開発 (b) を有するGoogle, Facebook, Amazon, Amazon の垂直統合型の企業であり, 現代の MLS は, Giaglis[13]が先行研究において指摘した 「MLS 提供者が多様な役割を分担しながら追 加サービスを提供していくという構造」とは 異なっていることを明らかにした。これらの 企業では, ショートレンジ(Wi-Fi など) の位 置情報取得技術を活用し, MLS の探索機能を 拡充させていることも見出した.

\section{参考文献}

[1] Manyika, J; Chui M Brown; B,Bughin J; Dobbs R Roxburgh C; Byers A. H (2011) "Big data: The next frontier for innovation, competition, and productivity" McKinsey Global Institute [2] Yue, Y; Lan, T; Yeh, A.G; Li, Q Q (2014) "Zooming into individuals to understand the collective: A review of trajectory-based travel behavior studies" Travel Behavior and Society 1 PP.69-78

[3] Steenbruggen, J; Borzacchiello M. T; Nijkamp, P; Scholten, H (2013) "Mobile phone data from GSM networks for traffic parameter and urban spatial pattern assessment: A review of applications and opportunities" GeoJournal, 78, PP.223-243.

[4] Musleh, B; García, F; Otamendi, J; Armingo J. M; De la Escalera, A (2010) "Identifying and tracking pedestrians based on sensor fusion and motion" stability predictions. Sensors, 10 PP.8028-8053.

[5] Calabrese, F; Ferrari, L; Blondel, V. D. (2014) "Urban sensing using mobile phone network data: a survey of research" ACM Computing Surveys (CSUR) 47(2), Article No. 25 [6] Dix, A; Rodden, T; Davies, N; Trevor, J; Friday, A; Palfreyman, K (2000) "Exploiting Space and Location as a Design Framework for Interactive Mobile Systems" ACM Transactions on Computer-Human Interaction, 7, 3, PP.285-321

[7] Long, S; Kooper, R; Abowd, G.D; Atkeson, C.G (1996) "Rapid Prototyping of Mobile ContextAware Applications: The Cyberguide Case Study. In the Proceedings of the2nd Annual International Conference on Mobile Computing and Networking" ACM Press, New York, PP.97-107. [8] Widhalm, P; Nitsche, P; Brändie, N. (2012) 
"Transport mode detection with realistic smartphone sensor data” In Pattern Recognition (ICPR), 2012 21st International Conference (PP. 573-576). IEEE.

[9] Nitsche, P; Widhalm, P; Breuss, S; Brändle, N; Maurer, P (2014) "Supporting large-scale travel surveys with smartphones - A practical approach" Transportation research part C, Emerging technologies PP.212-221

[10] Geurs, K. T; Thomas, T; Bijlsma, M; Douhou, S (2015) "Automatic trip and mode detection with move smarter: first results from the Dutch mobile mobility panel" Transportation Research Procedia, 11 PP.247-262.

[11] Johnson, C (1998) "Proceedings of the 1st Workshop on Human Computer Interaction with Mobile Devices" 21-23 May, GIST Technical Report G98-1, University of Glasgow

[12] Subhankar; Upker (2011) "Challenges and
Business models for mobile Location-based services and advertising" Communications of the ACM. May 2011. Vol. 54. No. 5

[13] George M, Giaglis (2003) "Towards a Classification Framework for Mobile Location Services" A Classification Framework for Mobile Commerce 2003 PP.64-81

[14]Tadahiko Kawai(2019)“'A Tentative Framework of Dynamic Platform Strategy -For the Era of GAFA and 5G-", Journal of Strategic Management Studies Vol. 11, No. 1, 19-36

[15] Juan Carlos Miguel de Bustos (2016) "Big data and Big GAFA. Thoughts on the data economy", Economia della Cultura, 2016, issue 4, PP.507-525 [16] Javad Rezazadeh, Kumbesan Sandrasegaran, Xiaoying Kong (2018) “A location-based smart shopping system with IoT technology" 2018 IEEE 4th World Forum on Internet of Things (WF-IoT)

(2021年 3 月 4 日 受付) (2021年 8月24日 採択) 